\title{
SAUDI WOMEN BEHAVIOR TOWARDS THE ACCEPTANCE OF INDUSTRIAL SMALL BUSINESS
}

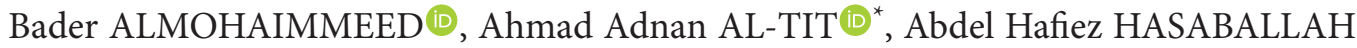 \\ Department of Business and Economics, College of Business and Economics (CBE), Qassim University, \\ KSA. Al Malida, Buraidah, 15452, Qassim, Kingdom of Saudi Arabia
}

Received 17 November 2019; accepted 31 March 2020

\begin{abstract}
The aim of this research was to canvass Saudi women's opinions about behavioral beliefs, i.e., attitudes, subjective norms and perceived behavioral control on their behavioral intention and hence adopting the small business initiative. Following the descriptive method, adopting the planned behavior theory PBT, a questionnaire consisted of 15 items was adapted to measure the variables of the research, i.e., three predictors, which are attitudes toward the behavior, subjective norms and perceived behavioral control, one mediating variable, which is behavioral intent and one dependent variable, which is the actual behavior. The questionnaire was electronically administered. A total of 724 questionnaires was collected in 2019. The results indicated that attitudes towards the behavior, subjective norms and perceived behavioral control had significant effects on behavioral intention, which in turn affect the target behavior. Behavioral intention had shown a mediating effect on the relationship between predictors and the response variable. Consequently, decision-makers are required to conduct awareness campaigns in order to promote the involvement in small businesses in the community, raising women's attitudes towards this type of business via success stories and full government support. Their perceived behavioral control can be enhanced through training to acquire business-related skills.
\end{abstract}

Keywords: planned behavior theory, Saudi women, industrial small business.

JEL Classification: J16, J18, J21, J22, J46, J71, J82, J83, D19.

\section{Introduction}

Saudi women enjoy a degree of respect and appreciation, and have privacy resulting from religious and social factors that contributed to reducing their freedom compared to women in Western society, and to make a change in their behavior and role in society came of the vision 2030 (CEDASA, 2016) to achieve this and made difficult decisions from the point of view of Saudi society.

The path of supporting entrepreneurship in small and medium enterprises is one of the tracks of the national transformation program within of Saudi vision 2030 (CEDASA, 2016). Predicting Saudi behavior towards these small businesses and achieving the desired goals in line with the Saudi vision is therefore an important issue. A well cited and established theory that can be used in this regard is the theory of planned behavior.

Ajzen and Fishbein $(1969,1980)$ introduced the theory of reasoned action by which the intention to practice a specific behavior can be predicted (Southey, 2011). In 1991,
Ajzen extended the model to fit the development in the variables and the result was a new model named the theory of planned behavior. The model comprised three independent variables, namely, the attitude toward behavior, subjective norm and perceived behavioral control, in addition to one mediating variable, which is behavioral intention as well as one dependent variable, which is the behavior.

An extensive review of the literature revealed that the theory of planned behavior had been applied in numerous fields, e.g., prediction of health-related behaviors (McEachan et al., 2011), use of networking websites (Pelling \& White, 2009), readiness of mobile learning in higher education (Cheon et al., 2012), exploring environmental behavioral intention in workplaces (Greaves, Zibarras, \& Stride, 2013), use of clinical guidelines by healthcare professionals (Kortteisto et al., 2010), entrepreneurial intent among students (Shook \& Bratianu, 2010), the role of self-identity (Rise, Sheeran, \& Hukkelberg, 2010), predicting consumer online buying intention (Hansen, Jensen, \& Solgaard, 2004), financial decision making in family firms

${ }^{\star}$ Corresponding author. E-mail: aa.altit@qu.edu.sa 
(Koropp et al., 2014), internet banking (Shih \& Fang, 2004) and predicting electronic commerce adoption (Pavlou \& Fygenson, 2006).

Concurrently, a specific vein of the literature covers using the theory of planned theory in the context of entrepreneurship research in business (Korunka et al., 2003; Van Gelderen et al., 2008; Gird \& Bagraim, 2008; Shook \& Bratianu, 2010; Kautonen, Van Gelderen, \& Tornikoski, 2013; Lortie \& Castogiovanni, 2015). Examples include intergenerational influence and entrepreneurial intent of small business (Carr \& Sequeira, 2007), predicting entrepreneurial intentions and actions (Kautonen, van Gelderen, \& Fink, 2015), adoption of information technology in small business (Harrison, Mykytyn Jr, \& Riemenschneider, 1997) and examining the entrepreneurial attitudes (Harris \& Gibson, 2008).

The theory of planned behavior has been found to be helpful in predicting and explaining human behavior. Gopi and Ramayah (2007) showed that the application of the theory of planned behavior was useful in predicting the behavioral intentions of internet stock trading among investors in Malaysia. Similar findings on the usefulness of the theory had been documented in the literature (De Groot \& Steg, 2007; Pelling \& White, 2009; Spence et al., 2018; Tommasetti et al., 2018).

The contribution of this paper lies to develop of a conceptual framework for the application of the planned behavior theory to Saudi women entrepreneurs based on the research by Ajzen and Fishbein $(1969,1980)$ and to provide evidence of the validity of the theory model as presented by the relevant previous studies.

On the other hands, this paper contributes to provide decision-makers in the Saudi Arabia to establish industrial cities on the extent of acceptance of Saudi women to work in these cities, which supports the plans of the decisionmaker, which supports the plans of the Kingdom in this direction or may require adjustment of decision-makers, and to know the most important factors that shape the behavior of Saudi women, Especially, the Saudi vision 2030 (CEDASA, 2016) towards a change in the role of Saudi women in society.

This research contributes to the improvement of the decision-making plans in addition to the importance of the research results for Saudi women themselves in detecting the behavioral influences that contribute to their acceptance of small industrial cities.

\section{Literature review and hypotheses development}

The theory of planned behavior is one of the most common theories used to predict human behavior (Andrew et al., 2016). It suggests that the behavioral intention is a function of three factors: the attitude toward the behavior, subjective norms and the perceived behavioral control (Baker \& White, 2010). The following sections discuss the three determinants of behavioral intention, their relationships with behavioral intention as well as the association between the behavioral intention and the actual behavior.

\subsection{Attitude toward the behavior}

According to Ajzen and Fishbein (1980), individuals' evaluations and expectations that performing a specific behavior will lead to particular outcomes refer to behavioral attitudes. Spence et al. (2018) described attitudes as positive or negative assessments of a particular behavior. Baker and White (2010) divided these evaluations into two types: affective and instrumental evaluations. According to them, affective evaluations picture a behavior as a pleasant or unpleasant one, while instrumental evaluations depict a behavior as easy or difficult. Looking at attitudes through these definitions means that individuals' positive attitudes have an effect on their behavioral intentions.

Actually, attitudes have been regarded as an antecedent of behavioral intention (Rhodes et al., 2015). In a research on the applicability of the theory of planned behavior in predicting the intention to trade online by Gopi and Ramayah (2007), positive relationships between attitude, subjective norm as well as perceived behavioral control and the behavioral intention. Predicting individuals' intention to use transferium in the Netherlands, De Groot and Steg (2007) highlighted that individuals' positive attitudes, positive subjective norms, and high perceived behavioral control were positively related to their behavioral intention to use transferium. According to the theory of planned behavior, attitudes have a direct effect on behavioral intention and an indirect effect on behavior as mediated by behavioral intention (Baker \& White, 2010).

Business startups are intentional processes affected by individuals' attitudes (Guerrero, Rialp, \& Urbano, 2008). In order to explore the effect of Saudi women's attitudes toward the acceptance of small business initiative on their behavioral intentions in this context, and to examine the mediating role played by their behavioral intentions in the relationship between their attitudes and the actual behavior, the following hypotheses were presumed:

H1a: The attitude toward behavior exerts a significant effect on the behavioral intention.

H1b: The behavioral intention significantly mediates the effect of the attitude toward behavior on the behavior.

\subsection{Subjective norms}

The second factor affecting the behavioral intention is the subjective norms of individuals. It has been defined as the perceived social pressure by individuals about conducting a certain behavior (De Groot \& Steg, 2007). For Spence et al. (2018), it refers to others' influences on the behavior. An example of social pressure sources is referent groups, which encourages or discourages a person from doing a particular behavior (Baker \& White, 2010), family members and friends (Davis et al., 2002).

Individuals' subjective norms had been found to be positively related to their behavioral intention (Davis et al., 2002; Greaves et al., 2003; Gopi and Ramayah, 2007; De Groot \& Steg, 2007; Pelling \& White, 2009). It was also assumed to have direct and indirect of on behavioral intention and behavior, respectively (Baker \& White, 2010). 
Subjective norms, as behavioral beliefs of individual, have successfully predicted their entrepreneurial intentions in several contexts, e.g., the USA and Northern European (Shook \& Bratianu, 2010).

Investigating the effect of subjective norms on Saudi women's behavioral intention as well as their actual behavior of accepting the initiative of small business entrepreneurship, the following hypotheses were assumed:

H2a: The subjective norm exerts a significant effect on the behavioral intention.

$\mathrm{H} 2 \mathrm{~b}$ : The behavioral intention significantly mediates the effect of the subjective norm on the behavior.

\subsection{Perceived behavioral control}

The perceived behavioral control, which the third behavior affecting the behavioral intention, has been defined as individuals' feelings of the ease or difficulty of conducting a particular behavior (De Groot \& Steg, 2007). In other words, it refers to individuals' perceived ability that they are able to exert a control on performing a particular behavior. It was presumed as a predictor of behavioral intention, which in turn postulated as a predictor of the behavior (Baker \& White, 2010).

For the purpose of identifying both direct and indirect effects of Saudi women perceived behavioral control of their actual behavior to accept the initiative of small business, the following hypotheses were suggested:

H3a: The perceived behavioral control exerts a significant effect on the behavioral intention.

$\mathrm{H} 3 \mathrm{~b}$ : The behavioral intention significantly mediates the effect of perceived behavioral control on the behavior.

\subsection{Behavioral intention and actual behavior}

Entrepreneurial activities fall under the concept of behavioral intention, which is supposed to lead to actual behavior. Planned behavior can be observed by observing behavioral intentions towards that behavior. Behavioral intentions are one of the important variables in which actual behavior can be predicted (Krueger Jr, Reilly, \& Carsrud, 2000). According to Ajzen and Fishbein (1980), behavioral intention will result in performing the actual behavior.

This relationship has been verified by researchers, where the results of the studies showed that behavioral intentions have a direct impact on actual behavior. Tommasetti et al's (2018) research aimed at identifying variables guiding customers to use sustainable restaurants adopting the theory of planned behavior and found that consumers' behavioral intentions were positively related to their actual behavior.

Using our data on the behavioral intentions of Saudi women that related to small business initiative, the effect of behavioral intentions on the actual behavior was investigated on the basis of the following hypothesis:

H4: The behavioral intention exerts a significant effect on the behavior.

\section{Methodology}

\subsection{Population, sample and data collection}

The population of the research consists of women business in Qassim region in Saudi Arabia who work in the four women industrial-zones that established to promote women entrepreneurship in the kingdom. A simple random sample comprised 1000 women was selected for the purpose of the current research. data were collected using an electronic questionnaire administered to the respondents in 2019. A total of 724 questionnaires was returned complete and valid for statistical analysis, with a cover ratio of $27.4 \%$.

\subsection{Instrument}

A questionnaire was developed in order to measure research variables based on related works (Ajzen \& Fishbein, 1980; Ajzen, 1991; Ajzen, 2002; Davis et al., 2002; De Groot \& Steg, 2007; Baker \& White, 2010). Items of the questionnaire were adapted to the Saudi environment and research objectives and a five-point Likert scale was used (strongly agree 5 points to strongly disagree 1 point).

Respondents' attitudes toward the behavior was measured by three items (TPB1-TPB3) (eg. Item I am keen to take advantage of new small business opportunities), their subjective norms were measured through three items (TPB4-TPB6) (eg. Item Confidence role of my family can support me to starting a small business), their perceived behavioral control was also measured by three items (TPB7-TPB9) (eg. Item Having confidence in the ability to manage the small business). Respondents' behavioral intentions were measured via three items (TPB10-TPB12) (eg. Item Choose the path of self-employment rather than work for others), Finally, respondents' target behavior was conceptualized using three items (TPB13-TPB15) (eg. Item I feel happy to work in small business). Reliability and validity of the instrument can be seen in the following section.

\subsection{Reliability and validity}

Composite reliability (CR) and Cronbach's alpha were used to assess reliability and convergent validity using the average variance extracted (AVE) was used to measure validity. CR and Cronbach's alpha ( $\alpha$ ) values should be greater than 0.70 (Al-Tit \& Hunitie, 2015; Almohaimmeed, 2019). The results of reliability and validity, as in Table 1, indicated that the measure is adequate. Factor loadings and the average variance extracted were greater than 0.5 , as well, reliability coefficients were higher than 0.7 (Al-Tit \& Hunitie, 2015; Almohaimmeed, 2017; Al-Tit, 2016; Al-Ayed, 2019). 
Table 1 . Results of reliability and validity

\begin{tabular}{|c|c|c|c|c|c|c|}
\hline Factor & $\begin{array}{l}\text { Items } \\
\text { No. }\end{array}$ & Items & $\begin{array}{c}\text { Standardized } \\
\text { Factor } \\
\text { Loadings }\end{array}$ & AVE & $\mathrm{CR}$ & $\alpha$ \\
\hline \multirow{3}{*}{ Attitude } & TPB1 & I am keen to take advantage of new small business opportunities & 0.84 & \multirow{3}{*}{0.73} & \multirow{3}{*}{0.89} & \multirow{3}{*}{0.87} \\
\hline & TPB2 & My positive view on small business failure I experienced & 0.81 & & & \\
\hline & TPB3 & I'm willing to risk whatever comes & 0.91 & & & \\
\hline \multirow{3}{*}{$\begin{array}{l}\text { Subjective } \\
\text { norms }\end{array}$} & TPB4 & $\begin{array}{l}\text { Confidence role of my family can support me to starting a small } \\
\text { business }\end{array}$ & 0.79 & \multirow{3}{*}{0.71} & \multirow{3}{*}{0.88} & \multirow{3}{*}{0.86} \\
\hline & TPB5 & $\begin{array}{l}\text { The existence of confidence in the efforts of those who are } \\
\text { considered important for me }\end{array}$ & 0.86 & & & \\
\hline & TPB6 & The support of friends so it can help me with a small business & 0.88 & & & \\
\hline \multirow{3}{*}{$\begin{array}{l}\text { Perceived } \\
\text { behavioral } \\
\text { control }\end{array}$} & TPB7 & Having confidence in the ability to manage the small business. & 0.85 & \multirow{3}{*}{0.73} & \multirow{3}{*}{0.89} & \multirow{3}{*}{0.88} \\
\hline & TPB8 & Leadership of humans may determine me in small business & 0.86 & & & \\
\hline & TPB9 & Starting a small business can instigate me to be creative & 0.85 & & & \\
\hline \multirow{3}{*}{$\begin{array}{l}\text { Behavioral } \\
\text { intentions }\end{array}$} & TPB10 & Choose the path of self-employment rather than work for others & 0.89 & \multirow{3}{*}{0.72} & \multirow{3}{*}{0.89} & \multirow{3}{*}{0.89} \\
\hline & TPB11 & $\begin{array}{l}\text { Choosing a work as an entrepreneur better than the labor force } \\
\text { in others }\end{array}$ & 0.83 & & & \\
\hline & TPB12 & $\begin{array}{l}\text { Planning to start a small business after acquiring the training } \\
\text { courses on entrepreneurship }\end{array}$ & 0.83 & & & \\
\hline \multirow{3}{*}{ Behavior } & TPB13 & I feel happy to work in small business & 0.91 & \multirow{3}{*}{0.76} & \multirow{3}{*}{0.90} & \multirow{3}{*}{0.89} \\
\hline & TPB14 & Working in a small business needs to do more & 0.87 & & & \\
\hline & TPB15 & I feel the need to develop my small business & 0.83 & & & \\
\hline
\end{tabular}

\section{Results and discussion}

\subsection{Measurement model}

The results of the measurement model via the confirmatory factor analysis (Hoque \& Awang, 2019) as presented in Figure 1 indicated that the indicators of the model with their associated factors, as revealed by the exploratory factor analysis, were significantly loaded with adequate values of goodness-of-fit indices.

Schreiber et al. (2006), Hooper, Coughlan, and Mullen (2008), Alkhamis (2018) Al-Tit, Omri, and Euchi (2019) suggested the following indices, by which model fit can be judged: Chi2/df $(<3)$, Comparative Fit Index GFI (> $0.90)$, Adjusted Goodness of Fit AGFI ( $>0.90)$, Normed Fit Index NFI ( $>0.90$ ), Comparative Fit Index CFI (> 0.90), Root Mean Square of Error Approximation RMSEA $(<0.08)$. For the current measurement model, it was concluded that all fit indices were within cut-off values. Chi2/ $\mathrm{df}=2.68$, GFI 0.919, AGFI $=0.889, \mathrm{NFI}=0.928, \mathrm{CFI}=$ 0.947 , RMSEA 0037. Based on these results, latent variables were reorganized to establish the structural model of the research as shown in the following section.

\subsection{Structural model}

The results of the structural model shown in Figure 2 assertained that the proposed hypotheses were supported by the current data. As summarized in Table 2, attitude had a significant effect on behavioral intention $(\beta=0.21, C . R .=$ $3.78, P=0.000)$, subjective norms has a significant effect on behavioral intention ( $\beta=0.46, C . R .=7.16, P=0.011)$, perceived behavioral control had a significant effect on behavioral intention ( $B=0.33$, C.R. $=5.51, P=0.001)$. behavioral intention, on the other hand, had a significant effect on behavior $(B=0.56, C . R .=11.3, P=0.000)$.

In order to figure out standardized direct and indirect effects of attitudes, subjective norms and perceived behavioral control of behavior through behavioral intention, exogenous factors were transformed using the main function. These effects are displayed in Figure 3 and elaborately recorded in Table 1.

The results in Table 2 surfaces that behavioral intentions significantly mediated the effects of attitude, subjective norms and perceived behavioral control of behavior. There was a significant indirect effect of attitude on behavior through behavioral intention $(B=0.083$., $\mathrm{P}=$ 0.002 ), a significant indirect effect of subjective norms on behavior ( $B=0.157$., $P=0.002)$ and a significant indirect effect of perceived behavioral control on behavior $(B=$ 0.137., $P=0.002$ ). Finally, the results confirmed that behavior intention had a significant effect of behavior $(B=$ 0.505, C.R. $=8.91, \mathrm{P}=0.002$ ).

Consequently, all hypotheses were accepted. That is, behavioral intention can be predicted by attitude, subjective norms and perceived behavioral control, and the former significantly predicted behavior. As well, behavioral intention played a mediated role in the effect of these behavioral beliefs on the actual behavior.

Ajzen and Fishbein (1980), who coined the theory of planned behavior, conceptualized individuals' behavioral attitudes in terms of their evaluations that encourage them to conduct a specific behavior. These evaluations lead 


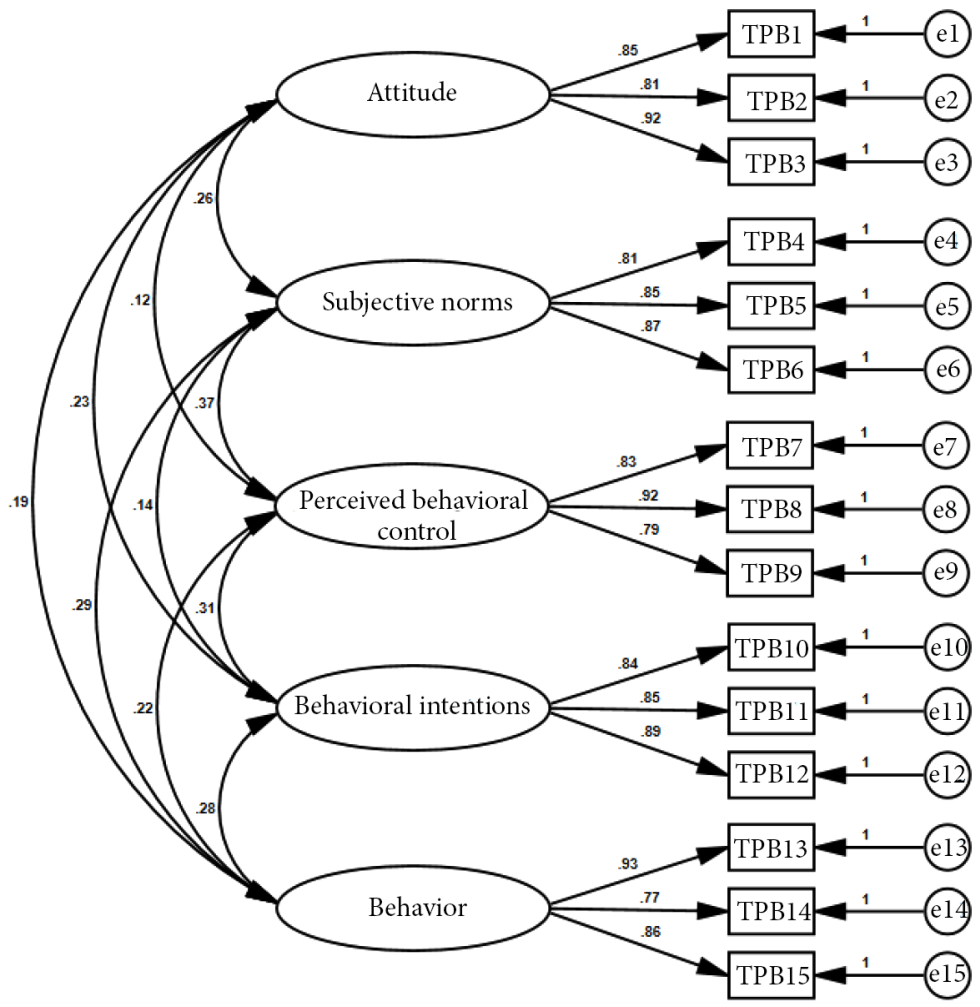

Figure 1. Research measurement model

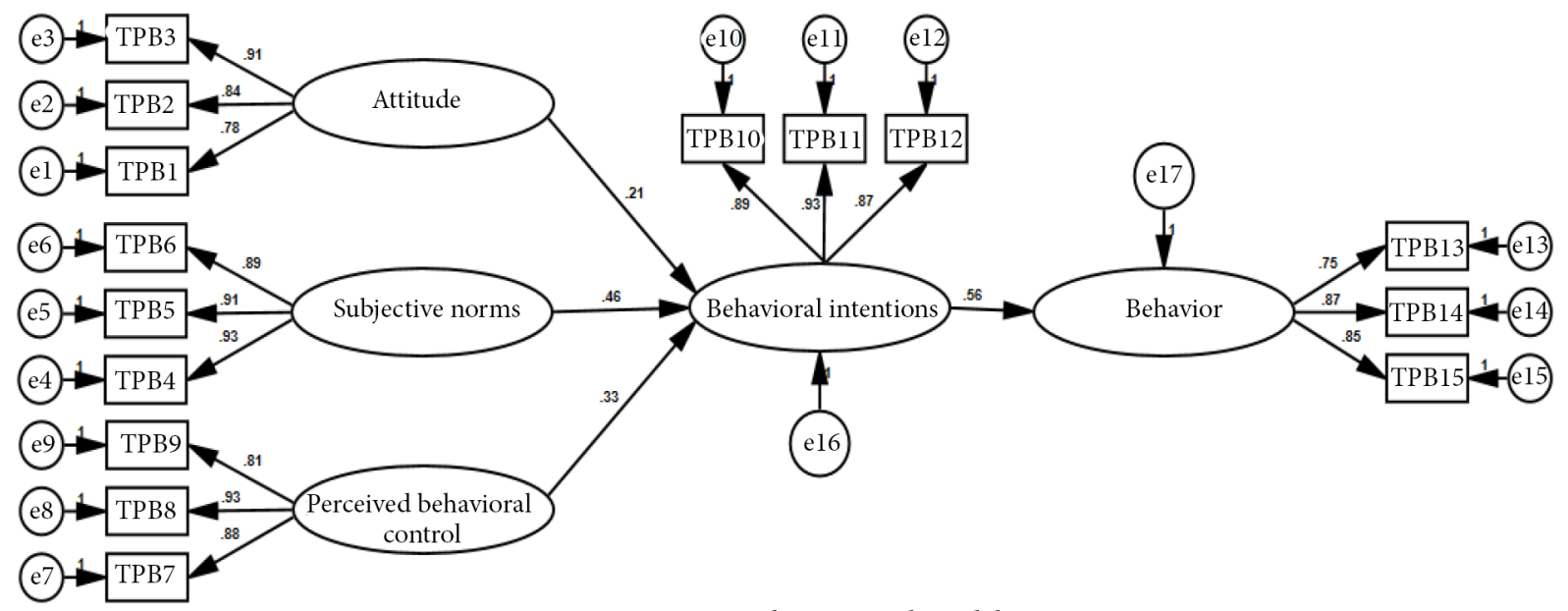

Figure 2. Research structural model

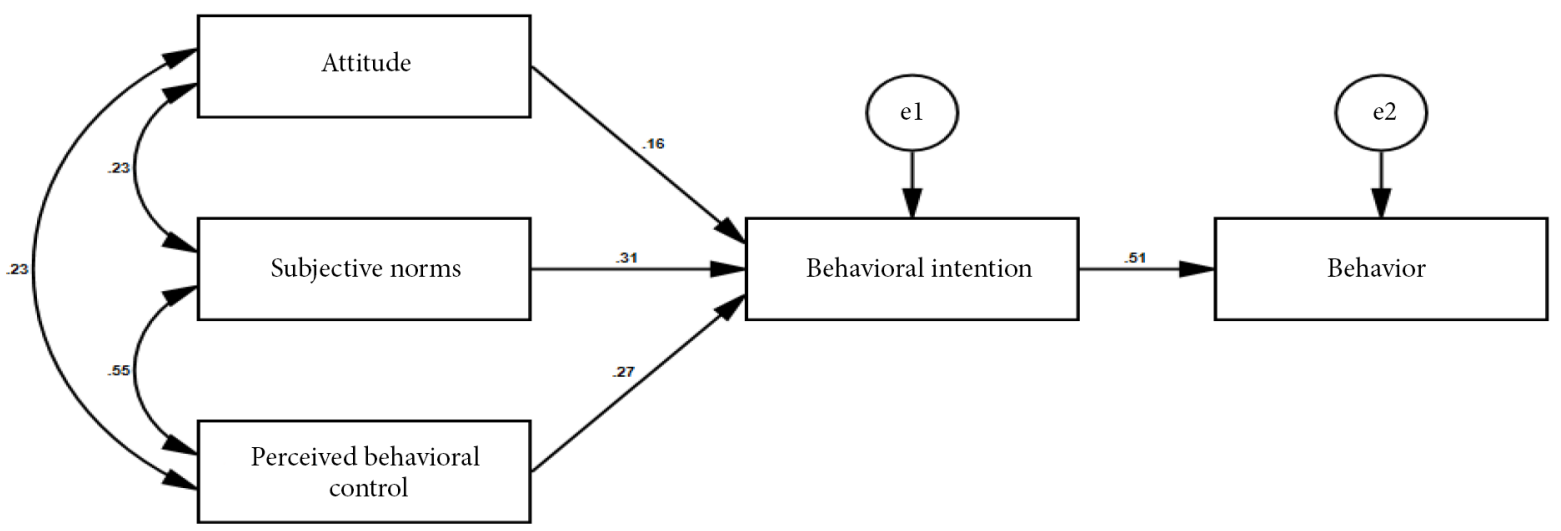

Figure 3. Research path model 
Table 2. Results of hypotheses testing

\begin{tabular}{|l|l|l|c|c|c|c|c|}
\hline \multicolumn{2}{|c|}{ Default Paths } & \multicolumn{3}{c|}{ Direct effects } & \multicolumn{2}{c|}{ Indirect effects } \\
\cline { 3 - 9 } & & $\beta^{*}$ & C.R. & $P^{* *}$ & $\beta^{*}$ & $P^{* *}$ \\
\hline Attitude & $\rightarrow$ & Behavioral intention & 0.164 & 2.84 & 0.000 & - & - \\
\hline Attitude & $\rightarrow$ & Behavior & - & - & - & 0.083 & 0.002 \\
\hline Subjective norms & $\rightarrow$ & Behavioral intention & 0.311 & 5.67 & 0.000 & - & - \\
\hline Subjective norms & $\rightarrow$ & Behavior & - & - & - & 0.157 & 0.002 \\
\hline Perceived behavioral control & $\rightarrow$ & Behavioral intention & 0.270 & 4.56 & 0.000 & - & - \\
\hline Perceived behavioral control & $\rightarrow$ & Behavior & - & - & - & 0.137 & 0.002 \\
\hline Behavioral intention & & Behavior & 0.505 & 8.91 & 0.000 & - & - \\
\hline
\end{tabular}

Notes: ${ }^{*}$ standardized effects; ${ }^{* *}$ significant at $\alpha=0.05$.

to negative or positive perceptions toward the behavior (Spence et al., 2018). They may view this behavior as good or bad, easy or difficult (Baker \& White, 2010). Logically, individuals' attitudes toward a particular behavior affect their intentions to perform that behavior (Rhodes et al., 2015). This was true for our results. In agreement with Gopi and Ramayah (2007) and De Groot and Steg (2007), positive attitudes toward the behavior was a key antecedent of behavioral intention, which in turn affects the target behavior. In a word, behavioral intention mediates the relationship between attitudes and the behavior (Baker \& White, 2010).

Subjective norms, are an influence exerts by other people (Spence et al., 2018), is another antecedent of behavioral intention. Perceptions of a social group such family members or friends (Davis et al., 2002) toward a specific behavior affect the individual's intention to perform that behavior or to keep from it (Baker \& White, 2010). In the current research, subjective norms was found to affect behavioral intention, which in turn affects the actual behavior. Similar findings were documented in related works (Greaves et al., 2003; Shook \& Bratianu, 2010; De Groot \& Steg, 2007; Gopi and Ramayah, 2007; Pelling \& White, 2009).

Perceptions of an individual about his or her ability to perform a particular behavior encourage or discourage him or her to adopt that behavior (De Groot \& Steg, 2007; Baker \& White, 2010). As we have already mentioned, the perceived ability to control a particular behavior affects the intention of the person to perform that behavior, which is the same finding of the present research. To this end, the behavioral intention of the individual to conduct a certain behavior influences his or her actual adoption of the behavior. This result, in fact, was confirmed using our data in agreement with Krueger Jr et al. (2000) and Tommasetti et al.s (2018). All in all, our results had gone well with the theory of planned behavior assumptions.

\section{Conclusions and practical implications}

The aim of this research is to canvass Saudi women's opinions about behavioral beliefs, i.e., attitudes, subjective norms and perceived behavioral control on their behavioral intention and hence adopting the small business initiative. Two of these factors belong to the person him or herself, which are attitudes toward behavior and perceived ability to control behavior. The third factor concerns others and their view of behavior, which is subjective norms. The research found that these three factors are positively related to behavior intention, which in turn affects the behavior.

Secondly, the results concluded that the behavioral intention mediates the relationship between attitudes, subjective norms as well perceived behavioral control and the behavior.

These results entail some implications. First, the strongest influence was due to subjective norms. This means that the decision-makers will carry out awareness campaigns that will demonstrate the importance of participation in small businesses, especially by Saudi women, both for women themselves and for the national economy. Of course, the aim of these campaigns is to create a kind of social change and encourage the involvement in these projects. These campaigns should also be directed to society in general and families and can be conducted in cooperation with community institutions.

On the other hand, policymakers are invited to encourage women to engage in small businesses by presenting success stories in this area, and to promote women's participation in these small businesses, especially as they receive full government support. It is necessary to provide continuous professional guidance that eliminates obstacles for women participating in these projects. Finally, improving women's perceived ability to enhance their behavioral intentions requires improving women's skills by providing appropriate training so that they are better able to carry out work tasks in small businesses.

\section{Limitations and future studies}

The present research is not without limitations. Although the size of the sample is rather large, all participants were from Al-Qassim region. Since the behavior is of a changing nature, cross-sectional studies, as the present research, are not sufficient to judge behaviors. Therefore, further studies should be carried out using samples that include more 
than one region in the Kingdom. These studies should be longitudinal in order to give more generalizable results to the population.

\section{Acknowledgements}

The authors would like to thank the respondents who participated in this research. They would also like to thank the Deanship of Scientific Research in Qassim University, Buraidah, Saudi Arabia.

\section{Disclosure statement}

The author(s) declared no potential conflicts of interest with respect to the research, authorship, and/or publication of this article.

\section{Funding}

The author(s) disclosed receipt of the following financial support for the research, authorship, and/or publication of this article: This research was funded by the Deanship of Scientific Research in Qassim University, Al Malida, Buraidah 15452, Qassim, Saudi Arabia.

\section{References}

Ajzen, I. (1991). The theory of planned behaviour. Organizational Behaviour and Human Processes, 50(2), 179-211. https://doi.org/10.1016/0749-5978(91)90020-T

Ajzen, I. (2002). Perceived behavioral control, self-efficacy, locus of control, and the theory of planned behaviour 1. Journal of Applied Social Psychology, 32(4), 665-683. https://doi.org/10.1111/j.1559-1816.2002.tb00236.x

Ajzen, I., \& Fishein, M. (1969). The prediction of behavioral intentions in a choice situation. Journal of Experimental Social Psychology, 5(4), 400-416. https://doi.org/10.1016/0022-1031(69)90033-X

Ajzen, I., \& Fishein, M. (1980). Understanding attitudes and predicting social behaviour. Englewood Cliffs, NJ.

Al-Ayed, S. (2019). The impact of strategic human resource management on organizational resilience: an empirical research on hospitals. Business: Theory and Practice, 20, 179-186. https://doi.org/10.3846/btp.2019.17

Alkhamis, F. (2018). The mediating role of employee job performance in the impact of open book management dimensions on customer satisfaction. Business: Theory and Practice, 19, 157-165. https://doi.org/10.3846/btp.2018.16

Almohaimmeed, B. (2017). Restaurant quality and customer satisfaction. International Review of Management and Marketing, 7(3), 42-49.

Almohaimmeed, B. (2019). Internal service quality and external service quality using two versions of SERVQUAL scale: An empirical evidence from five malls in the capital city of Saudi Arabia. Business: Theory and Practice, 20, 158-169. https://doi.org/10.3846/btp.2019.15

Al-Tit, A. (2016). The impact of lean supply chain on productivity of Saudi manufacturing firms in Al-Qassim region. Polish Journal of Management Studies, 14(1), 18-27. https://doi.org/10.17512/pjms.2016.14.1.02
Al-Tit, A., \& Hunitie, M. (2015). The mediating effect of employee engagement between its antecedents and consequences. Journal of Management Research, 7(5), 47-62. https://doi.org/10.5296/jmr.v7i5.8048

Al-Tit, A., Omri, A., \& Euchi, J. (2019). Critical success factors of small and medium-sized enterprises in Saudi Arabia: Insights from sustainability perspective. Administrative Sciences, 9(32), 1-12. https://doi.org/10.3390/admsci9020032

Andrew, B., Mullan, B., de Wit, J., Monds, L., Todd, J., \& Kothe, E. (2016). Does the theory of planned behaviour explain condom use behaviour among men who have sex with men? A meta-analytic review of the literature. AIDS and Behavior, 20(12), 2834-2844. https://doi.org/10.1007/s10461-016-1314-0

Baker, R., \& White, K. (2010). Predicting adolescents' use of social networking sites from an extended theory of planned behaviour perspective. Computers in Human Behavior, 26(6), 1591-1597. https://doi.org/10.1016/j.chb.2010.06.006

Carr, J., \& Sequeira, J. (2007). Prior family business exposure as intergenerational influence and entrepreneurial intent: A theory of planned behavior approach. Journal of business research, 60(10), 1090-1098.

https://doi.org/10.1016/j.jbusres.2006.12.016

Cheon, J., Lee, S., Crooks, S., \& Song, J. (2012). An investigation of mobile learning readiness in higher education based on the theory of planned behavior. Computers \& Education, 59(3), 1054-1064. https://doi.org/10.1016/j.compedu.2012.04.015

Council of Economic and Development Affairs of Saudi Arabia CEDASA. (2016). Saudi Vision 2030, KSA (April 2016). http://vision2030.gov.sa/en

Davis, L., Ajzen, I., Saunders, J., \& Williams, T. (2002). The decision of African American students to complete high school: An application of the theory of planned behavior. Journal of Educational Psychology, 94(4), 810. https://doi.org/10.1037/0022-0663.94.4.810

De Groot, J., \& Steg, L. (2007). General beliefs and the theory of planned behavior: The role of environmental concerns in the TPB. Journal of Applied Social Psychology, 37(8), 1817-1836. https://doi.org/10.1111/j.1559-1816.2007.00239.x

Gird, A., \& Bagraim, J. (2008). The theory of planned behaviour as predictor of entrepreneurial intent amongst final-year university students. South African Journal of Psychology, 38(4), 711-724. https://doi.org/10.1177/008124630803800410

Gopi, M., \& Ramayah, T. (2007). Applicability of theory of planned behavior in predicting intention to trade online: Some evidence from a developing country. International Journal of Emerging Markets, 2(4), 348-360. https://doi.org/10.1108/17468800710824509

Greaves, M., Zibarras, L., \& Stride, C. (2013). Using the theory of planned behavior to explore environmental behavioral intentions in the workplace. Journal of Environmental Psychology, 34, 109-120. https://doi.org/10.1016/j.jenvp.2013.02.003

Guerrero, M., Rialp, J., \& Urbano, D. (2008). The impact of desirability and feasibility on entrepreneurial intentions: A structural equation model. International Entrepreneurship and Management Journal, 4(1), 35-50. https://doi.org/10.1007/s11365-006-0032-x

Hansen, T., Jensen, J., \& Solgaard, H. (2004). Predicting online grocery buying intention: a comparison of the theory of reasoned action and the theory of planned behavior. International Journal of Information Management, 24(6), 539-550. https://doi.org/10.1016/j.ijinfomgt.2004.08.004 
Harris, M., \& Gibson, S. (2008). Examining the entrepreneurial attitudes of US business students. Education + Training, 50(7), 568-581. https://doi.org/10.1108/00400910810909036

Harrison, D., Mykytyn Jr, P., \& Riemenschneider, C. (1997). Executive decisions about adoption of information technology in small business: Theory and empirical tests. Information Systems Research, 8(2), 171-195.

https://doi.org/10.1287/isre.8.2.171

Hooper, D., Coughlan, J., \& Mullen, M. (2008). Structural equation modelling: Guidelines for determining model fit. Electronic Journal of Business Research Methods, 6(1), 53-60. https://doi.org/10.21427/D7CF7R

Hoque, A., \& Awang, Z. (2019). Does gender difference play moderating role in the relationship between entrepreneurial marketing and Bangladeshi SME performance? Accounting, 5(1), 35-52. https://doi.org/10.5267/j.ac.2018.6.001

Kautonen, T., van Gelderen, M., \& Fink, M. (2015). Robustness of the theory of planned behavior in predicting entrepreneurial intentions and actions. Entrepreneurship Theory and Practice, 39(3), 655-674. https://doi.org/10.1111/etap.12056

Kautonen, T., Van Gelderen, M., \& Tornikoski, E. (2013). Predicting entrepreneurial behaviour: a test of the theory of planned behaviour. Applied Economics, 45(6), 697-707. https://doi.org/10.1080/00036846.2011.610750

Koropp, C., Kellermanns, F., Grichnik, D., \& Stanley, L. (2014). Financial decision making in family firms: An adaptation of the theory of planned behavior. Family Business Review, 27(4), 307-327. https://doi.org/10.1177/0894486514522483

Kortteisto, T., Kaila, M., Komulainen, J., Mäntyranta, T., \& Rissanen, P. (2010). Healthcare professionals' intentions to use clinical guidelines: a survey using the theory of planned behaviour. Implementation Science, 5(1), 51. https://doi.org/10.1186/1748-5908-5-51

Korunka, C., Frank, H., Lueger, M., \& Mugler, J. (2003). The entrepreneurial personality in the context of resources, environment, and the startup process - A configurational approach. Entrepreneurship Theory and Practice, 28(1), 23-42. https://doi.org/10.1111/1540-8520.00030

Krueger Jr, N., Reilly, M., \& Carsrud, A. (2000). Competing models of entrepreneurial intentions. Journal of Business Venturing, 15(5-6), 411-432. https://doi.org/10.1016/S0883-9026(98)00033-0

Lortie, J., \& Castogiovanni, G. (2015). The theory of planned behavior in entrepreneurship research: what we know and future directions. International Entrepreneurship and Management Journal, 11(4), 935-957. https://doi.org/10.1007/s11365-015-0358-3

McEachan, R., Conner, M., Taylor, N., \& Lawton, R. (2011). Prospective prediction of health-related behaviours with the theory of planned behaviour: A meta-analysis. Health Psychology Review, 5(2), 97-144.

https://doi.org/10.1080/17437199.2010.521684
Pavlou, P., \& Fygenson, M. (2006). Understanding and predicting electronic commerce adoption: An extension of the theory of planned behavior. MIS Quarterly, 30(1), 115-143. https://doi.org/10.2307/25148720

Pelling, E., \& White, K. (2009). The theory of planned behavior applied to young people's use of social networking web sites. CyberPsychology \& Behavior, 12(6), 755-759. https://doi.org/10.1089/cpb.2009.0109

Rhodes, R., Beauchamp, M., Conner, M., de Bruijn, G., Kaushal, N., \& Latimer-Cheung, A. (2015). Prediction of depotbased specialty recycling behavior using an extended theory of planned behavior. Environment and Behavior, 47(9), 10011023. https://doi.org/10.1177/0013916514534066

Rise, J., Sheeran, P., \& Hukkelberg, S. (2010). The role of selfidentity in the theory of planned behavior: A meta-analysis. Journal of Applied Social Psychology, 40(5), 1085-1105. https://doi.org/10.1111/j.1559-1816.2010.00611.x

Schreiber, J., Stage, F., King, J., Nora, A., \& Barlow, E. (2006). Reporting structural equation modeling and confirmatory factor analysis results: A review. The Journal of Educational Research, 99(6), 323-337. https://doi.org/10.3200/JOER.99.6.323-338

Shih, Y., \& Fang, K. (2004). The use of a decomposed theory of planned behavior to research Internet banking in Taiwan. Internet Research, 14(3), 213-223. https://doi.org/10.1108/10662240410542643

Shook, C., \& Bratianu, C. (2010). Entrepreneurial intent in a transitional economy: an application of the theory of planned behavior to Romanian students. International Entrepreneurship and Management Journal, 6(3), 231-247.

https://doi.org/10.1007/s11365-008-0091-2

Southey, G. (2011). The theories of reasoned action and planned behaviour applied to business decisions: A selective annotated bibliography. Journal of New Business Ideas \& Trends, 9(1), 43-50.

Spence, M., Stancu, V., Elliott, C., \& Dean, M. (2018). Exploring consumer purchase intentions towards traceable minced beef and beef steak using the theory of planned behavior. Food Control, 91, 138-147. https://doi.org/10.1016/j.foodcont.2018.03.035

Tommasetti, A., Singer, P., Troisi, O., \& Maione, G. (2018). Extended theory of planned behavior (ETPB): Investigating customers' perception of restaurants' sustainability by testing a structural equation model. Sustainability, 10(7), 2580. https://doi.org/10.3390/su10072580

Van Gelderen, M., Brand, M., van Praag, M., Bodewes, W., Poutsma, E., \& Van Gils, A. (2008). Explaining entrepreneurial intentions by means of the theory of planned behaviour. Career Development International, 13(6), 538-559. https://doi.org/10.1108/13620430810901688 